\title{
Where HaVe All The Women Gone?
}

\section{A. ANNE MCLELlAN*}

It is a pleasure to be here this evening at the end of that which I know has been a stimulating and challenging set of panel discussions on lawyers and the legal profession in the twenty-first century.

I do not intend to revisit your discussions of earlier today. When thinking about the perspective I might offer this evening, I reflected upon my time as Minister of Justice and Attorney General of Canada as it related to your conference theme. Ministers of Justice are regularly faced with the assertion that the public is losing, or worse, has lost, confidence in the justice system and in key participants within the system, particularly lawyers (and to a much lesser degree judges). The public continues to express a high degree of confidence in the police.

There have been many surveys, polls, and focus groups done, both in Canada and around the world, regarding confidence in aspects of the justice system, as well as the respect or trust to be placed in key actors in the system. For example:

(1) Ipsos Reid (June 2007) - 62 percent of Canadians expressed confidence in the courts; 88 percent expressed confidence in the police; 52 percent expressed confidence in the prison system; and 41 percent expressed confidence in the parole system. ${ }^{1}$

(2) Leger Marketing (May 2007) - the Profession Barometer listed those occupational categories that Canadians trust the most, finding that the percentage of Canadians who trust police officers to be 84 percent; judges 74 percent; lawyers 52 percent; politicians 15 percent; and used car salespeople 12 percent. $^{2}$

(3) The Harris Poll (August 2007) - only 22 percent of respondents identified lawyers as having great prestige, having fallen 14 percent since $1977 ;^{3}$ in a Harris Poll published in August 2006, only 27 percent of respondents indicated that they would generally trust lawyers to tell the truth. ${ }^{4}$

A. Anne McLellan, P.C., B.A., LL.B., LL.M., LL.D. (Hon.), is with the law firm of Bennett Jones LLP and is the Interim Academic Director and Distinguished Scholar in Residence at the Institute for United States Policy Studies at the University of Alberta. This speech was delivered at the closing dinner of the 100th Anniversary Conference of the Law Society of Alberta.

Ipsos Reid, "Canadians Perceive Crime Increases to be less Acute in their Communities" (June 2007). Leger Marketing, OmniCan Report, "Professional Barometer" (15 May 2007) at 3. See also Andrea Sands, "Public faith in justice system declining: report" Edmonton Journal (15 October 2007) A13, in which 73 percent of Albertans said that they felt confident about the justice system, a decline of 6 percent since 2003-2004.

3 The Harris Poll \#77, "Firefighters, Scientists and Teachers Top List as 'Most Prestigious Occupations,' According to Latest Harris Poll” (1 August 2007).

The Harris Poll \#61, "Doctors and Teachers Most Trusted Among 22 Occupations and Professions: Fewer Adults Trust the President to Tell the Truth" (8 August 2006). 
This issue of public confidence is an important one for elected officials and especially for Ministers of Justice. In its most extreme form, loss of public confidence in the legal system will undermine the rule of law and call into question the fairness and impartiality of the system, its most important hallmarks.

What are the systemic and structural issues that may lead to a loss of confidence? What kinds of conduct on the part of key players in the system may lead to a loss of confidence? And what are the appropriate responses on the part of a Minister of Justice, and indeed, the state, to these issues?

This is not an unimportant question because if confidence is lost, depending on its causes, Ministers of Justice will recommend to their colleagues that action be taken. But there is a caveat here: while governments will act in response to a loss of public confidence in the legal system, my experience has been that there is little sense of urgency around action, in sharp contrast to, say, the health care system. When the public's confidence slips in reaction to an apparent lack of timely access to health care services, it is seen by governments as a crisis that requires Federal/Provincial/Territorial meetings, leads to requests for infusions of large amounts of new money that are invariably met, and creates a general air of societal concern that has the potential to move votes. Loss of public confidence in the legal system, while much reported and commented upon, does not engender the same sense of crisis nor feelings of personal vulnerability for most of us, and therefore you can expect much slower response times on the part of politicians.

All this to say that assertions of loss of public confidence in the legal system, if sustained over time, will evoke reaction from elected officials. This reaction can take many forms: the most immediately useful would be to increase funding for criminal and civil legal aid to provide access to lawyers for a larger number of the working poor and the middle class in a wider range of matters. ${ }^{5}$

The lack of public confidence might lead to calls for legislative restrictions upon the powers of self-regulation of the legal profession - for example, in relation to discipline, fee setting, or admission qualifications. Or it might lead to more mandatory minimum sentences in the criminal justice system, thereby stripping out judicial discretion, the perennial "whipping boy" of many who express little confidence in the ability of our legal system to provide "just" results for victims of crime.

While all of this is timely and important, this evening I want to talk about an issue that some might not see, immediately or directly, as one of confidence in our profession. Last

Access to justice issues have become a major concern especially for judges who are seeing more unrepresented people appearing before them. The Chief Justice of Canada, Beverley McLachlin, now speaks of this issue often. See e.g. "Remarks of the Right Honourable Beverley McLachlin, P.C., Chief Justice of Canada" (Remarks presented to the Council of the Canadian Bar Association at the Canadian Legal Conference, Calgary, Alberta, 11 August 2007). One of the ways to ameliorate the access issue is to increase funding by governments, both federal and provincial, to legal aid programs; another approach is to increase the amount and type of pro bono work being done by the profession. See, for example, the Law Society of Alberta's (LSA) recent decision to create Pro Bono Law Alberta, online: LSA < http://www.lawsocietyalberta.com/centennialprobono.cfm>. 
year, I took up the challenge for the Liberal Party of Canada, as part of a renewal process, to look at why more women were not standing for elected office. As I prepared for this evening, I was struck by the similar themes I was hearing and reading about in relation to both why so few women stand for elected office and why significant numbers of women leave the (private) practice of law.

For me, this is an issue of confidence in the legal system. I believe that just as an elected legislative body should be a mirror of the community it claims to represent, so too should an influential and powerful profession like that of law, which claims to act in the public interest.

What does a person see when she or he looks at a picture of the profession? Do we see women in equal numbers to men (women represent 52 percent of the population, and well over 50 percent of first year law classes have been female for years)? Do we see women as partners and managing partners in major law firms? Do we see women who work the same or more hours than their male counterparts, on similar files, earn similar salaries? The answer, it seems to me, is only sometimes.

More women are graduating from law school and being admitted into practice. But how many stay in practice and for how long? I will give you some idea. According to the Federation of Law Societies of Canada (FLSC), statistics show that for those who have been in practice for more than 26 years, the breakdown by gender is 11 percent female and 89 percent male; for 16-20 years, 33 percent female and 67 percent male; and for $0-5$ years, 54 percent female and 46 percent male. ${ }^{6}$

I graduated from Dalhousie Law School in 1974. Ours was the first class with a significant number of women. From then on, more and more women entered law school, and more and more graduated, often at the top of their classes. So, we should expect to see commensurate numbers of women in all the justice-related occupations and especially in private practice. But, we do not. So, I ask you, "Where have all the women gone"?

It is not that the question of gender diversity has gone unaddressed by the legal profession. Quite the contrary: for at least 20 years, national organizations like the Canadian Bar Association (CBA), provincial law societies, law schools, and others have been expressing support for diversity within the profession, in its many dimensions, but especially as it relates to gender diversity. The CBA established its Task Force on Gender Equality in the Legal Profession in 1991 and its Final Report was issued in August 1993. ${ }^{8}$

Federation of Law Societies of Canada (FLSC), 2005 Law Societies Statistics, online: FLSC $<\mathrm{http}: / /$ www.flsc.ca/en/pdf/statistics2005.pdf $>$ at 4 .

7 This was a question asked of me in the context of women's political participation by a young woman in Charlottetown, P.E.I. at one of the roundtables held to hear women's views on why more women were not standing for political office. She commented that in high school and university, her experience had been that young women were the Presidents of Students' Councils and Students' Unions; they were editors of student newspapers; they were the student leaders. But in the context of participation in partisan politics, they had disappeared. They were not holding positions in constituency associations, or provincial or national associations of political parties; they were not expressing interest in standing for elected office. So her question: "Where have all the women gone?"

8 Canadian Bar Association Task Force on Gender Equality in the Legal Profession, Touchstones For Change: Equality, Diversity and Accountability (Ottawa: Canadian Bar Association, 1993). 
The Task Force began its work 16 years ago, and the concerns were well-known and documented: the legal profession was not environmentally friendly to women; women lawyers in virtually all sections of the profession faced barriers presented by the failure to accommodate their child-bearing and child-rearing functions; and the profession was not inclusive of women of colour, Aboriginal women, disabled women, and lesbian women. ${ }^{9}$ In the Final Report of the Task Force, the former Justice Bertha Wilson asked whether the profession was ready for equality of opportunity for all women. ${ }^{10}$ I think that we still are waiting for the answer.

Here in Alberta, the Law Society has been actively studying the profession's adaptability to greater numbers of women since 1991, when it established a Special Committee entitled "Women in the Legal Profession" (of which I was a member). The mandate of the Committee was:

(1) to ascertain the current status of women in the profession;

(2) to ascertain whether women encountered barriers to full and equal participation in the profession and;

(3) if barriers did exist, what actions, if any, the Law Society should take. ${ }^{11}$

It was accepted by most women ( 97.2 percent) and men ( 77.6 percent) in 1991 that there was bias against women in the legal profession. ${ }^{12}$ Large numbers of women reported discrimination on the basis of their gender, both from male lawyers and from clients. ${ }^{13}$ Complaints of sexual harassment were common, as were complaints of discrimination in hiring, remuneration, and advancement.

Taking a snapshot of the profession at 20-year intervals is probably an appropriate thing to do. As I mentioned, it was 1971 when women started entering law schools in significant numbers. Twenty years later in 1991, many of those women could have been practising for about 15 years; therefore, time to take stock and assess how the profession had adapted to significant numbers of women. It is probably time to take stock once again. Significant time has passed since the major recommendations for change in the CBA Report and the original work done by law societies, like Alberta's. How has the profession changed or adapted to the increasing numbers of women? How do women view the adaptability of the profession that they have chosen to enter?

The Law Society of Alberta (LSA) followed up on its original work on gender bias in a recent Report of the Joint Committee on Equality, Equity, and Diversity. ${ }^{14}$ The Committee was motivated, in part, by the fact that while equal numbers of men and women had entered

Ibid. at 2-4.

Ibid. at 5 .

Law Society of Alberta, Women and the Legal Profession in Alberta: Highlights of the Survey of Active Members (Calgary: Law Society of Alberta, 1992) at Introduction.

Ibid. at 11 .

Ibid.

Merrill Cooper, Joan Brockman \& Irene Hoffart, Final Report on Equity and Diversity in Alberta's Legal Profession (26 January 2004), online: LSA <http://www.lawsocietyofalberta.com/files/reports/ Equity_and_Diversity.pdf $>$ 
the profession over the preceding decade, it appeared that women lawyers had "been leaving the profession in greater numbers and proportions than men." 15

Both active and inactive members were surveyed. Inactive members, both men and women, left practice to look for more personally-rewarding opportunities, to avoid the stress of the adversarial approach to law, and to find more time for a personal life. Half of the inactive respondents said that if they had to do it all over again that they would not become a lawyer. ${ }^{16}$

Active members, especially younger lawyers, expressed dissatisfaction with the structure of the practice of law: the hours of work, the lack of work/life balance, the profit-driven culture of the profession, "the tyranny of billable hours," and a culture driven by pursuit of profits rather than justice. ${ }^{17}$

Some 12 years after the LSA's first survey on these issues, we find that there are still 92 percent of women and 69 percent of men who think that there is some form of bias or discrimination against women in the profession. ${ }^{18}$

It was interesting to note that 91 percent of lawyers of colour felt that they were discriminated against in the profession. Seventy-three percent of lawyers with disabilities and 88 percent of gay and lesbian lawyers also believed that there is discrimination within the profession. And, while very few Aboriginal lawyers completed the survey, the few who did indicated there is extensive discrimination throughout the legal profession. ${ }^{19}$

Respondents reported that discrimination was most commonly manifested in the form of: racist and sexist comments; denial of opportunities to work on files; exclusion from workrelated social or business development activities related to career advancement; and negative career consequences as a result of having children and the attendant parental responsibilities. Sexual harassment also continued to be identified as a problem. ${ }^{20}$

In fairness, the survey results indicated that discrimination had decreased and this was especially true of the overt, intentional kinds. However, the types of discrimination that continued to be practised against women go to the very heart of their ability to succeed in private practice, and one presumes, therefore, impact directly on their decisions to stay or leave. The types of discrimination identified were in relation to:

(1) assignment of files and work;

(2) the relative weight given to their opinions (the presumption of competence) $;^{21}$

\footnotetext{
Ibid. at Executive Summary.

Ibid.

Ibid.

Ibid.

Ibid.

Ibid.

It appears that men benefit from a presumption that they are competent while women still have to prove their competency. A similar presumption operates in politics and within many senior management teams in the private sector.
} 
(3) remuneration; and

(4) access to clients and managerial positions.

I would sum these factors up under the general rubric of "career advancement."

In addition, respondents indicated a general perception that "mommy tracking" began before a woman had even begun to think about having children, and that as a general rule, only women who do not have children or whose children are older are able to advance in big firms. $^{22}$

Not surprisingly, the majority of women respondents agreed that discrimination against women is more significant in private practice than in government or when working as inhouse counsel. ${ }^{23}$

This helps explain a FLSC statistic that I found interesting: practising members exempted from insurance were 52 percent male and 48 percent female. ${ }^{24}$ Contrast that with practising members insured, where the numbers are 70 percent male and 30 percent female. ${ }^{25}$ Why do we find so many more women working for government or as in-house counsel? It is not that the work is easier or less challenging in substance; some of the most complex and important legal issues are dealt with by government lawyers on a daily basis and in today's world of quickly changing expectations, rules, and laws around corporate governance and responsibility, in-house counsel must be on top of their files.

My guess is that more women work for government or as in-house counsel because of the culture and structure of the workplace: there is no tyranny of billable hours; there is no preset timetable for becoming partner; these workplaces are much less competitive as between lawyers; and invariably, there are both maternity and parental leave (usually up to 12 months). There are more flexible work schedules so Mom or Dad can work half-time or parttime if they are the primary caregiver. These are workplaces much more conducive to the work/life balance for which many women look, especially those who are primary caregivers, so that they can continue to contribute in a meaningful way to their profession and their family's economic well-being, while at the same time discharging family and community obligations.

But three times the number of lawyers are in private practice than working for government or as in-house counsel. So perhaps we need to return, not to my original question of "where have all the women gone," because we may be getting at least a partial answer to that question, but ask instead whether we care where they have gone and if we do, what can our profession do about it, if anything?

Supra note 14 at 165 . See also supra note 14 at Executive Summary: the Report concludes that women's advancement is still seriously hindered by the fact that they bear children and that little progress has been made in the private sector to accommodate parenting by both men and women, although the consequences are largely borne by women.

$23 \quad$ Ibid. at 166

$24 \quad$ Supra note 6 at 2.

25 Ibid. 
I think we all care. I do not question for a moment that organizations like the CBA and the LSA, and their sister bodies across the country, care about this. There is objective evidence of their caring: Task Force Reports; Equity and Diversity Committees; Equity Ombudspersons or Officers; and Guidelines for, among other things, parental and maternity leave, alternate work schedules, gender-inclusive communications, harassment policies, violence policies, bereavement, compassionate and family responsibility policies, and equality in employment interview guidelines. ${ }^{26}$

I honestly believe that the governing bodies of our profession have listened to the recommendations of their various task forces and committees, and I believe that they have acted, for the most part, in good faith. I believe they have shown "awareness" if not always "leadership" on these issues over the last 20 years.

So, why are we still confronted with the challenge of significantly larger numbers of women choosing to leave the private practice of law than their male counterparts? And generally leaving during the critical 5-7 year period, when they might be considered for partner.

We all know the answers. It is about the inability to achieve work/life balance, especially if you are a primary caregiver; it is about the culture and structure of private practice, especially private practice in large law firms. And as most of you know, this is becoming an issue not only for women but for younger men. Focus groups of male and female law students in the 2004 survey done by the LSA "expressed dismay about a perceived conflict between maintaining 'life balance' and practising in their desired area of law." 27

Law societies, as regulators with the best of intentions, have proven unable to transform the traditional structures of law practice. Regulation, even when carried out with a commitment to best practices, has its limitations for a profession like law. After 13 years in government, I am well aware of the limitations of regulatory regimes to effect desired societal change. Law societies can establish guidelines; they can inform, educate and cajole; they can discipline their members who are proven guilty of discrimination, harassment, or other forms of misconduct. But the culture and structure of private practice has remained remarkably stable, or perhaps more appropriately, static.

Many would suggest, including Deborah Rhode, in her book entitled In the Interests of Justice: Reforming the Legal Profession, ${ }^{28}$ that the "priority of profit" stands in the way of meaningful change. She says that money is a way of keeping score and that spending money is a way to signal achievement and social status: "And the increasingly public nature of personal salaries has made the scoring competition easier to play and harder to win." 29

These are all offices, programs, or policies that the LSA has developed over the past 20 years. For a complete listing, see Law Society of Alberta, Diversity and Equality Initiatives: 1991-2006 (March 2006), online: LSA <http://www.lawsocietyalberta.com/files/reports/Equality_Diversity_Initiatives_ 2006.pdf>.

$27 \quad$ Supra note 14 at 163.

28 Deborah L. Rhode, In the Interests of Justice: Reforming the Legal Profession (Oxford: Oxford University Press, 2000). 
Rhode also makes the point that many organizations employing lawyers have difficulty giving higher priority to anything else. Since money is at the top of almost everyone's scale, it is easier to reach consensus on financial rewards than on other values such as shorter hours, flexible work schedules, or pro bono commitments. ${ }^{30}$

Perhaps we can turn this "priority of profit" to our advantage. Profit requires willing workers, especially junior associates, the "worker bees" of most law firms. Perhaps if this next generation of lawyers, both female and male, say, in sufficient numbers, that this is not the way we want to work and live, and that there are other places where we can employ our education and talents, then, maybe the "priority of profit" will require new and more flexible structures of practice. And remember, women graduates will continue to outnumber men and more of the top students will be women. Competitive advantage will lie with hiring these top students, investing in them, and keeping them. And keeping them will require an understanding that at some point, the majority of these women will want to have children and will become primary caregivers at least for some period of time.

We also need to encourage a new generation of leaders and managers in law firms: people who understand and have training in modern human resource strategies and who understand that flexible structures in the workplace, which provide for the elusive work/life balance for which so many lawyers are looking, can increase productivity, job satisfaction, and retention. If law firms think of themselves as businesses and act more and more like businesses, then maybe we should expect that key members of firms, perhaps members of the executive committee or the senior managing partner, take the same kinds of management and leadership courses that now are required for senior managers and leaders in other businesses. "Tone at the top" is key to change. And if those who have influence and power in law firms (real or perceived) signal that new and more flexible ways of practising law are not only tolerated but also actively encouraged and valued, then things will begin to change.

No one suggests that changing the culture and structure of the practice of law will be either easy or simple, but change it must. We need functional workplaces where being a long-term, senior associate is valued and respected; where the quality of one's work matters more than the number of hours billed; where "being visible" to the senior partners matters less than actually getting the job done for the client; and where pro bono work is seen not as a nice thing to do if one has time, but is actively encouraged and is given value by those who make decisions about compensation and performance.

Recently, I heard former British Prime Minister Tony Blair speak about global relations. Whatever one may think about any individual policy of the Blair government, he is articulate, thoughtful, and candid about the decisions he made and why he made them. When asked about finding a fair and just solution to the on-going crisis in the Middle East, he said that you must "work, work, work" and never lose your sense of optimism. ${ }^{31}$

31 Tony Blair, "Building Global Relations - An Afternoon with Tony Blair" (Telus Convention Center, Calgary, Alberta, 26 October 2007).
} 
I thought that what he said had application here. We have a serious challenge to transform the practice of law into a modern, functional workplace where the talents of all our people can be maximized, while acknowledging the diversity of their lives. So I think we "work, work, work" with a sense of optimism about the possibility of on-going change. And we have reason to be optimistic. Over these past 20 years, there has been positive change - not enough, but it is significant nonetheless. So, we must believe, that with work and optimism, further change will happen. 